\title{
Buku Literasi Augmented Reality sebagai Media Pendukung Pembelajaran Aspek Keaksaraan AUD
}

\author{
Dwi Hartanti ${ }^{1 凶}$, Mozes Kurniawan ${ }^{1}$ \\ Pendidikan Guru Pendidikan Anak Usia Dini, Universitas Kristen Satya Wacana Salatiga, \\ Indonesia ${ }^{(1)}$ \\ DOI: 10.31004/obsesi.v6i4.2042
}

\begin{abstract}
Abstrak
Banyaknya pembelajaran yang ditemui berbentuk worksheet yang dikerjakan dirumah, menjadikan anak bosan. Anak lebih memilih bermain gadgetnya. Penelitian ini bertujuan mengembangkan buku literasi berbasis augmented reality sebagai media pendukung pembelajaran aspek keaksaraan anak usia dini khususnya pada Bahasa Indonesia dan Bahasa Inggris dasar dalam pembelajaran di masa pandemi COVID-19. Menggunakan jenis Research and Development. Produk yang dikembangkan adalah media Augmented Reality yang di dalamnya berisikan media pembelajaran kosakata yang berbasis games bagi anak, berbentuk animasi 3D. Subjek penelitian adalah siswa TK yang ada di Salatiga. Teknik pengumpulan data dilakukan dengan observasi, wawancara dan kuesioner yang dibagikan diberbagai sekolah. Hasil penelitian didapatkan dengan adanya teknologi akan menjadikan pembelajaran lebih optimal dan juga kreatif sehingga dapat merangsang berkembangnya daya pikir, kreativitas dan bahasa dalam rangka menumbuhkan sikap, mentalitas dan moral yang baik.
\end{abstract}

Kata Kunci: augmented reality; bahasa indonesia; bahasa inggris; research and development; media pembelajaran

\begin{abstract}
Many of lessons found in the form of worksheets that are done at home makes children bored. Children prefer to play with their gadgets. This study aims to develop an augmented realitybased literacy book as a media to support learning aspects of early childhood literacy, especially in Indonesian and basic English in learning during the COVID-19 pandemic. This study uses the type of Research and Development. The product developed in this research is Augmented Reality media which contains game-based vocabulary learning media for children, in the form of 3D animation. The research subjects in this study were kindergarten students in Salatiga. Data collection techniques were carried out by observation, interviews and questionnaires distributed in various schools. The existence of technology will make learning more optimal and creative so that it makes learning that functions to stimulate the development of thinking, creativity and language in order to foster good attitudes, mentality and morals.
\end{abstract}

Keywords: augmented reality; english language learning; research and development; learning media; indonesian language learning

Copyright (c) 2022 Dwi Hartanti, Mozes Kurniawan

$\triangle$ Corresponding author :

Email Address: 272017010@student.uksw.edu (Salatiga, Indonesia)

Received 1 October 2021, Accepted 28 December 2022, Published 21 January 2022 


\section{PENDAHULUAN}

Pendidikan anak usia dini memegang peran yang sangat penting dalam perkembangan anak, karena merupakan pondasi dasar dalam kepribadian anak. Anak yang berusia 0-8 tahun memiliki masa perkembangan kecerdasan yang sangat pesat, sehingga masa ini disebut golden age (masa emas). Golden age sangat penting dan perlu diperhatikan khususnya oleh orang tua. Pada Golden age otak bertumbuh secara maksimal, begitu pula pertumbuhan fisik, juga terjadi perkembangan kepribadian anak dan pembentukan pola perilaku, sikap dan ekspresi emosi. Jika berbagai kebutuhan anak diabaikan pada masa golden age, anak di khawatirkan mengalami tumbuh kembang yang kurang optimal.

Maka dari itu, penting bagi orangtua untuk mengenal setiap tahapan perkembangan anak serta memberikan perlakuan dan stimulasi yang sesuai dengan tahap perkembangannya. Dengan sendirinya pola-pola berjalan, berbicara, merasakan, berpikir atau pembentukan pengalaman harus dipelajari. Adanya minat yang bersifat tidak alami, akan tetapi adanya dorongan-dorongan potensi tertentu akan membentuk dasar-dasar dari minat apa saja yang dikembangkan anak di lingkungan tempat ia tumbuh dan berkembang (Indrawati, 2017).

Untuk dapat mendukung pertumbuhan dan perkembangannya anak usia golden age ini, maka orang tua harus lebih memberikan dukungan yang dapat diberikan kepada anak yaitu waktu, dorongan, sarana, lingkungan, hubungan yang harmonis dalam keluarga, cara mendidik yang baik, serta kesempatan untuk memperoleh pengetahuan, (Indrawati, 2017). Potensi yang tidak kalah pentingnya bagi perkembangan kecerdasan anak yaitu pengembangan keaksaraan pada anak usia dini.

Mengenal keaksaraan awal adalah kemampuan setiap anak untuk mengenal huruf dan bunyi bahasa. Kemudian gabungan huruf menjadi kata yang sederhana. Banyak orangtua menuntut sudah harus bisa membaca, menulis dan berhitung. Bahkan dibeberapa sekolah yang ada di Salatiga, sekolah dasar mengajukan persyaratan tes calistung untuk penerimaan siswa baru. Hal ini menjadi kekhawatiran orangtua sehingga timbul keinginan untuk cenderung memaksakan anak untuk bisa calistung setelah lulus dari TK.

Meski banyak permasalahan mengenai Calistung (Novita, 2020) pengenalan literasi pada anak usia dini sebenarnya boleh dilakukan asalkan sesuai dengan lingkup STTPA anak dan memperhatikan cara belajar anak, agar pengenalan literasi ini tidak sampai pada kesalahan penggunaan prinsip pembelajaran anak usia dini. (Novita, 2020)

Pada Peraturan Menteri Pendidikan dan Kebudayaan Republik Indonesia Nomor 137 tahun 2014 (Permendikbud, 2014) tentang Standar Nasional Pendidikan Anak Usia Dini, pasal 10 berbunyi 'keaksaraan, mencakup pemahaman terhadap hubungan bentuk dan bunyi huruf, meniru bentuk huruf, serta memahami kata dan cerita'. Jadi dapat dikatakan bahwa anak usia dini perlu untuk dapat memahami komponen-komponen keaksaraan yang berupa kosa kata, memahami suatu cerita dan dimungkinkan adanya kegiatan bermain yang dapat menstimulusi kemampuan membuat goresan huruf sebagai wujud perkembangan aspek keaksaraan. Pada prinsipnya harus adanya dorongan pengembangan optimal untuk potensi peserta didik melalui pengalaman belajar bermakna, agar mereka memiliki kesiapan menempuh jenjang pendidikan selanjutnya. Salah satu yang dapat menjadi dorongan dalam optimalisasi potensi perkembangan kebahasaaan anak yakni adanya integrasi hal yang kreatif, inovatif dan menarik seperti teknologi.

Salah satu yang berkembang hari-hari ini adalah teknologi pembelajaran virtual dengan visualisasi yang menarik ketika belajar dirumah (Musabikhah \& Usman, 2021). Banyak yang menafsirkan kesiapan menempuh jenjang Pendidikan selanjutnya dengan kemampuan baca, tulis dan hitung sehingga sampai saat ini tetap ada orangtua yang menganjurkan anaknya kursus membaca, menulis dan berhitung. Dan hal ini salah, kalau anak belum siap (Yulaelawati, 2016).

Pada usia 4-6 tahun, kemampuan berbahasa anak akan berkembang sejalan dengan rasa ingin tahu serta sikap antusiasnya yang tinggi. Sehingga timbul pertanyaan-pertanyaan 
dari anak dengan kemampuan bahasanya. Kemampuan berbahasa juga akan terus berkembang sejalan dengan intensitas berkomunikasi dalam pergaulan anak dengan teman sebayanya, karena anak akan belajar tentang bagaimana berinteraksi dengan oranglain. Dan dengan memperlihatkan suatu minat anak yang meningkat terhadap aspek-aspek bahasa tulis/baca, ia senang mengenal kata-kata yang menarik baginya dan mencoba menulis kata yang sering ditemukan. Anak juga senang belajar menulis namanya sendiri atau kata-kata yang berhubungan dengan suatu yang bermakna baginya. Anak usia 4-5 tahun kalimat yang dimiliki sudah terdiri dari empat sampai lima kata, mereka juga mampu menggunakan kata depan seperti 'di bawah', 'di dalam', 'di atas' dan 'di samping'. Sedangkan pada usia 5-6 tahun, kalimat anak sudah terdiri dari enam sampai delapan kata. Mereka juga Sudah dapat menjelaskan arti kata yang sederhana dan juga mengetahui lawan kata. Juga dapat menggunakan kata penghubung (Syaodih, 2019).

Keaksaraan awal merupakan tanda bahwa anak sudah berproses untuk menjadi aksarawan. Ini yang harus ditumbuhkan, yaitu proses untuk menjadi aksarawan, bukan untuk menjadi anak pintar calistung. Keaksaraan awal merupakan tatanan pondasi untuk menguasai kemampuan membaca dan menulis serta berhitung yang menyenangkan. Keadaan keaksaraan awal ini harus dikembangkan dengan baik dan tidak dialihkan dengan penguasaan keaksaraan konvensional yang akan melelahkan anak dan menimbulkan pengalaman negatif terhadap membaca dan menulis. Keaksaraan awal dapat dibangun sejak dini melalui peran serta orang dewasa dalam kegiatan bermakna yang melibatkan berbicara dan aksara.

Anak-anak yang menunjukkan kemampuan literasi berupa membaca sejak dini akan menjadi pembaca yang sukses, praktik literasi pada pembelajaran anak usia dini akan berpengaruh juga pada kemampuan awal anak dan juga akan memberikan efek yang longitudional bagi perkembangan kemampuan berbahasa anak, (Novita, 2020)

Bahasa sebagai alat komunikasi, menjadi efektik jika seorang individu berkomunikasi dengan orang lain. Menurut (Gunarti, 2018). Dan juga menurut (Nurlaeni, 2020) menjelasakan bahwa Bahasa merupakan ungkapan pikiran dan perasaan yang dilakukan secara baik, karena dengan Bahasa orang dapat mengenal kebutuhannya dengan baik. Dengan demikian dapat dipahami bahwa Bahasa menjadi aspek yang sangat penting bagi manusia untuk melakukan kontak antara satu dengan lainnya sebagai tujuan tertentu.

Bahasa memiliki peran sentral dalam perkembangan intelektual, sosial dan emosional anak. Pembelajaran Bahasa diharapkan dapat membantu anak mengenal dirinya, budayanya, budaya oranglain, mengemukakan gagasan dan perasaan, berpartisipasi dalam masyarakat serta menggunakan kemampuan analitis dan imaginative yang ada dalam dirinya (Rosaliana, 2011). Dari pernyataan ini memberi penegasan bahwa anak perlu dibekali dengan kemampuan Bahasa sejak dini agar dengan kemampuan Bahasa yang dimiliki anak dapat mengembangkan aspek-aspek perkembangan lainnya. Dengan demikian guru perlu mengetahui tahap-tahap perkembangan Bahasa anak usia dini sehingga dapat memberi stimulasi edukatif yang bermakna guna mengoptimalkan aspek-aspek perkembangan Bahasa pada anak (Dhiu, 2021).

Dimasa pandemi COVID-19 memberikan dampak dan pengaruh pada keberlangsungan layanan dilembaga pendidikan, terutama Pendidikan anak usia dini. Adanya risiko jangka panjang akibat pandemi COVID-19 ini yaitu alat belajar nondigital yang saat ini sudah tidak dapat digunakan secara optimal karena sarana dan prasarana yang diberikan oleh orangtua tidak seperti yang diberikan oleh guru kepada murid saat pembelajaran normal disekolah, lalu alat peraga edukatif yang tidak bisa di permainkan karena hanya tersedia atau dimainkan di sekolah, yang tidak memungkinkan anak untuk datang kesekolah atau dibawa pulang menjadikan APE tersebut tidak terpakai dengan optimal. Dan juga adanya ketidakseimbangan capaian pembelajaran karena dengan adanya COVID-19 menjadikan capaian pembelajaran dan juga kompetensi pembelajaran dan indikator perkembangan yang sudah ditetapkan oleh lembaga sekolah tidak sepenuhnya 
tercapai, karena ada komponen tertentu yang sulit untuk dikerjakan, misalnya dalam perkembangan anak, selama belajar dari rumah guru hanya bisa memantau lewat video atau foto yang dikirimkan oleh orangtua, dan orangtua juga mencacatkan hasil perkembangan ke dalam lembar observasi orangtua, terkadang orangtua mengisinya perkembangan anak tersebut tercapai supaya anaknya terlihat baik dalam perkembangannya atau gengsi terhadap orangtua murid lainnya. Lalu tidak ada akses kegiatan pendukung pembelajaran. Sedangkan saat ini pelaksanaannya, pembelajaran rumah dengan metode yang berupa pemberian worksheet tidaklah efektif, karena kebanyakan orangtua yang mengerjakan. Faktor kurang semangat anak dan penerapan metode pembiasaan. Dari suasana hati dan emosi anak yang seringkali berubah secara tiba-tiba membuat orangtua merasa bingung dan kewalahan. Tidak semua orangtua paham bagaimana menghadapi anak yang berperilaku tidak sesuai harapan. Dalam situasi ini, tidak jarang orangtua gagal dalam membentuk komunikasi dengan anak. Alih-alih memahami perilaku anak, justru orangtua malah lebih sering marah dan membentak anak. Oleh karena itu, penambahan unsur pembelajaran yang memotivasi anak diperlukan khususnya media yang mampu membuat anak tertarik untuk belajar dan melakukan pembiasaan-pembiasaan pembelajaran yang akan menstimulasi perkembangan bahasanya (Yemima, Wijayaningsih, Kurniawan, 2019)

Proses pembelajaran dari rumah melalui pembelajaran jarak jauh idedalnya tetap dapat mengakomodasi kebutuhan belajar siswa untuk mengembangkan bakat dan minat sesuai jenjang pendidikannya. Untuk mewujudkan hal ini diperlukan kesiapan pendidik, kurikulum yang sesuai, ketersediaan sumber belajar, serta dukungan perangkat dan jaringan yang stabil sehingga komunikasi antar peserta didik dan pendidik dapat berjalan dengan baik. Kondisi pembelajaran jarak jauh saat ini belum dapat dikatakan ideal karena masih terdapat berbagai hambatan yang dihadapi.

Hambatan tersebut menjadi tantangan dalam pelaksanaan pembelajaran jarak jauh mengingat pembelajaran jarak jauh merupakan keharusan agar kegiatan Pendidikan tetap dapat terselenggara di tengah darurat pendemi COVID-19 yang terjadi saat ini. Hambatan yang dihadapi dalam pelaksanaan pembelajaran jarak jauh salah satunya adalah keterbatasan sarana dan prasarana, juga dukungan teknologi (Arifa, 2020).

Terdapat berbagai alternatif pembelajaran dimasa pandemi saat ini yaitu online learning. Menurut (Vijayani, 2013), seiring dengan kemajuan system teknologi informasi, dunia pendidikan akan bergerak secara dinamis dalam menciptakan media, metode dan materi pembelajaran yang lebih menarik, interaktif dan komprehensif. Oleh karena itu dunia pendidikan harus mampu memanfaatkan teknologi informasi untuk mengembangkan system pendidikan.

Melihat hal ini, tidak di pungkiri dunia informatika mengalami perkembangan sangat pesat dikarenakan tuntutan belajar harus maksimal demi sukses dan tercapainya tujuan Pendidikan. Saat ini layanan Pendidikan banyak dilakukan melalui jaringan atau yang sering dikenal dengan Daring. Dari berbagai aplikasi salah satunya virtual Zoom Meeting. Pembelajaran virtual dengan aplikasi Zoom Meeting dapat dilaksanakan untuk anak usia dini. Pertemuan zoom merupakan media pembelajaran yang efektif digunakan untuk meningkatkan kemampuan keaksaraan anak. Adanya kesempatan untuk berinteraksi jarak jauh pada anak sangat membantu guru untuk meningkatkan kompetensi keaksaraan sebagai bekal untuk menempuh jenjang Pendidikan selanjutnya. Dan adanya pembelajaran virtual dapat melatih kemampuan anak dalam menggunakan teknologi guna dalam menghadapi revolusi industry, (Usman, 2021)

Perkembangan teknologi saat ini sangat mendukung proses pembelajaran yang modern, salah satunya Augmented Reality, yaitu penggabungan antara dua dunia, dunia maya ke dunia nyata. Dengan kata lain benda dalam dunia maya dapat ditampilkan ke dunia nyata (Yaoyuneyong, 2011). Metode Augmented Reality ini memiliki kelebihan dari sisi interaktif, yaitu pembuat dapat menampilkan objek 3D dari buku 2D dengan cara mengarahkan $A R$ kamera ke dalam obyek buku tertentu. Selain itu penerapan konsep yang akan digunakan 
diharapkan dapat meningkatkan daya nalar pemahaman anak mengenai buah atau sayuran dalam bahasa Indonesia maupun Bahasa inggris dan daya imajinasi anak untuk menerapkan pemahaman tersebut dalam kehidupan sehari-hari. Augmented Reality dalam Pendidikan tidak hanya dapat meningkatkan efektivitas keaktifan belajar anak, tetapi juga mendorong meningkatkan perkembangan pemahaman buah-buahan dan atau sayuran dalam dua bahasa, berpikir kritis, perkembangan emosional, kecerdasan dan imajinasi anak dengan melihat benda-benda nyata menjadi lebih interaktif (Ozarslan, 2012).

Media pembelajaran ini nantinya dapat di akses dengan gadget dalam memainkannya. Dengan adanya pembelajaran menggunakan gadget akan mendapatkan informasi dan pengetahuan melalui lingkungan belajar interaktif dengan berbagai konteks menggunakan portable teknologi yang disebut dengan telepon genggam. Maka peserta didik bebas dan mudah untuk mengakses materi pembelajaran (Kurniawan, 2017).Dan dengan adanya media pembelajaran berbasis $A R$ ini dapat mengatasi kebosanan belajar anak, karena didalamnya terdapat macam-macam permainan yang berasal dari buku ditransferkan ke dalam bentuk nyata (3D).

Harapannya, dengan adanya pembelajaran berbasis Augmented Reality ini, dapat meningkatkan pengembangan aspek keaksaraan anak usia dini dalam berbahasa, dan juga meningkatkan kreativitas berbahasa melalui Augmented Reality bagi anak usia dini dalam mempersiapkan pendidikan selanjutnya. Dan juga membantu orangtua dalam menemani belajar anak dari rumah yang saat ini membutuhkan media pembelajaran yang menarik yang bisa dikerjakan di rumah juga fleksible yang bisa dibawa kemana saja.

Dengan adanya teknologi akan menjadikan pembelajaran lebih optimal dan juga kreatif sehingga menjadikan pembelajaran yang berfungsi merangsang berkembangnya daya pikir, kreativitas dan bahasa dalam rangka menumbuhkan sikap, mentalitas dan moral yang baik. Selain itu juga membantu meningkatkan kualitas pembelajaran anak dalam berbagai aspek perkembangan (Yemima, Wijayaningsih, Kurniawan, 2019).

\section{METODOLOGI}

Penelitian yang digunakan yaitu RnD. Penelitian ini dilakukan kurang lebih enam bulan. Penelitian pengembangan sebagai proses digunakan untuk mengembangkan dan memvalidasi produk Pendidikan (Gall, 2020). Di dalamnya mempelajari temuan penelitian yang berkaitan dengan produk yang akan dikembangkan, mengembangkan produk berdasarkan temuan ini, bidang pengujian dalam pengaturan dimana ia akan digunakan akhirnya, dan merevisinya untuk memperbaiki kekurangan yang mungkin ditemukan dalam tahap mengajukan pengujian (Mulyana, 2020). Produk yang akan dikembangkan adalah Buku Literasi Berbasis Augmented Reality.

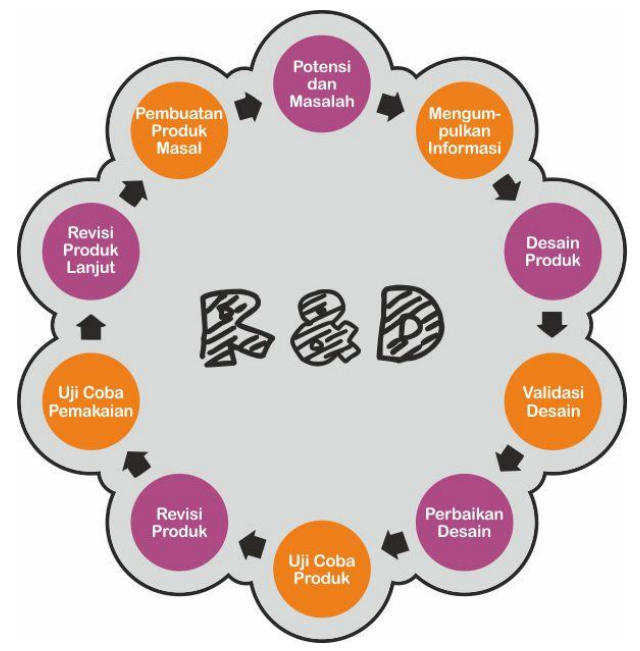

Gambar 1. Tahapan Utuh Penelitian RnD 
Langkah-langkah penelitian dan pengembangan menurut (Sugiono, 2012) menyatakan bahwa, ada sepuluh tahap penelitan research and development, yaitu ; potensi dan masalah, pengumpulan data, desain produk, validasi desain, uji coba pemakaian, revisi produk, uji coba produk, revisi desain, revisi produk, produksi masal. Tahaoan tersebut dapat dilihat diilistrasikan pada gambar 1.

Dari pernyataan tersebut, peneliti mengambil beberapa Langkah penelitian research and development menurut (Sugiono, 2012) yaitu; (a) potensi dan masalah; (b) pengumpulan data; (c) desain produk; (d) validasi desain; (e) revisi desain. Berikut Langkah penelitian dan pengembangan pada gambar 2 .

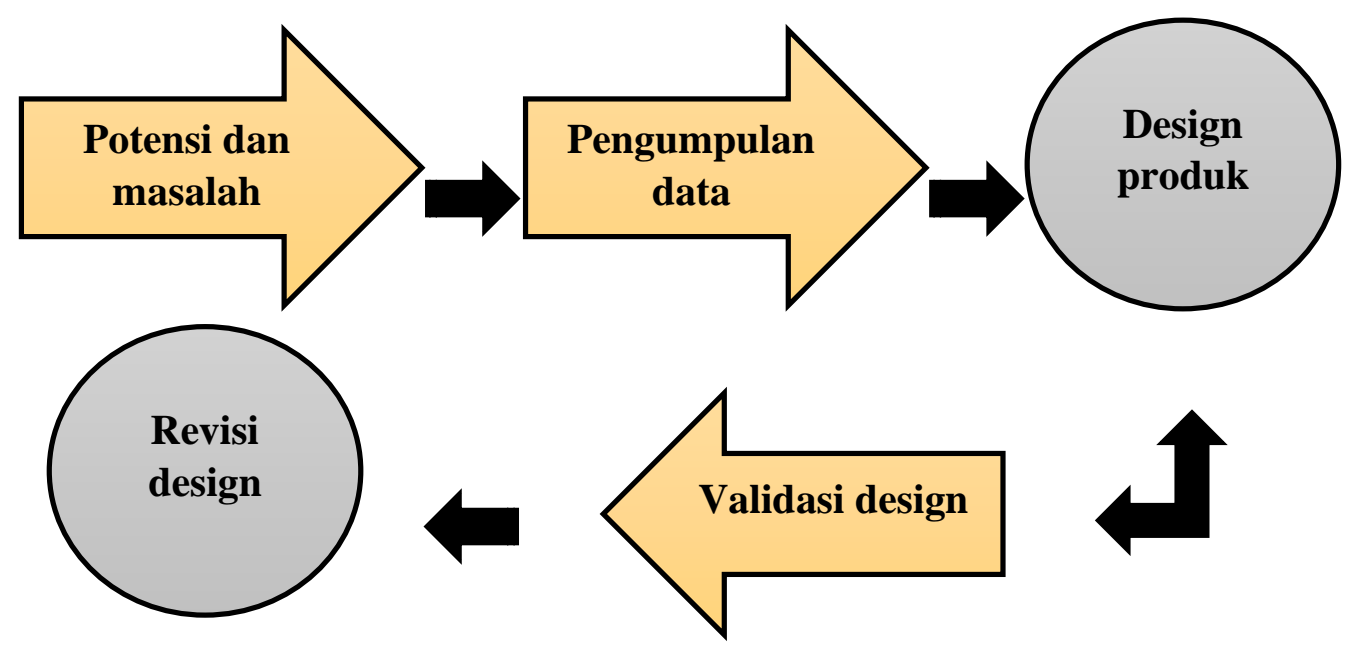

Gambar 2: Tahap Penelitian RnD yang Digunakan

Informasi yang dikumpulkan peneliti berkaitan dengan pembelajaran keaksaraan anak usia dini melalui buku literasi berbasis augmented reality guna meningkatkan kosa kata keaksaraan pada anak usia dini di sekolah TK yang ada di Salatiga. Berdasarkan data yang diperoleh, penulis membuat design produk terlebih dahulu. Design produk di susun sesuai dengan indikator pencapaian perkembangan untuk meningkatkan keaksaraan pada anak usia 5-6 tahun, yang nantinya design produk ini akan dikonsultasikan kepada ahli media dan ahli materi untuk di validasi.

Validasi desain dilakukan dengan menghadirkan beberapa pakar atau ahli yang sudah berpengalaman untuk menilai produk baru yang dirancang. Pakar yang dihadirkan terdiri dari ahli materi dan ahli media. Ahli materi dan ahli media nantinya akan menilai desain yang telah dibuat untuk mengetahui kelemahan dan kekuatan desain berdasarkan pemikiran rasional yang dilakukan di dalam forum diskusi. Setelah validasi desain media buku literasi berbasis augmented reality dilakukan melalui diskusi dengan ahli materi dan ahli media, maka dapat diketahui kelemahan atau kekurangan yang terdapat dalam desain media buku literasi berbasis augmented reality yang dibuat. Selanjutnya, kelemahan tersebut akan diperbaiki oleh peneliti agar selanjutnya layak diuji cobakan.

\section{HASIL DAN PEMBAHASAN}

Penulis mengamati, bahwa pelaksanaan yang dilakukan khususnya pembelajaran yang dilakukan saat ini daring, banyak ditemukan berbagai kendala dalam pelaksanaan pembelajaran daring. Salah satunya, guru yang kurang menguasai teknologi yang ada, dan tidak bisa memecahkan masalah pada saat teknologi yang digunakan mengalami kendala secara tiba-tiba, disini proses pembelajaran akan mengalami keterhambatan dan proses pembelajaran tidak berjalan dengan baik. 
Dari kejadian diatas, semua guru dituntut untuk bisa up-to-date, apalagi dengan perkembangan zaman yang saat ini semakin maju. Semua guru harus bisa dan dituntut menggunakan dan menerapkan berbagai macam teknologi dengan berbagai macam yang mungkin baru mereka jumpai, dan hanya guru-guru muda saja yang bisa mengikuti dengan baik. Untuk para guru senior akan kalah cepat untuk memahaminya. Perlunya ada edukasi bagi guru mengenai teknologi yang saat ini sedang berkembang, jadi ketika pembelajaran seperti saat ini dilakukan, guru siap menghadapi permasalahan yang mungkin akan tiba-tiba muncul dan dapat mengatasinya dengan baik proses pembelajaran.

Selain itu, belum optimalnya penerapan media pembelajaran yang kreatif dan inovatif yang dapat digunakan dirumah karena terbatasnya media yang dimiliki oleh peserta didik. Karena terdapat media dirumah pun, orangtua belum tentu bisa menggunakan dan menerapkannya kepada anak, juga fasilitas disekolah dengan dirumah akan berbeda, jika di sekolah anak bisa belajar dan bermain dengan berganti-ganti permainan beberapakali, dirumah permainan yang mungkin terbatas, maka media tersebut menjadi tidak berfungsi dengan maksimal.

Dan dalam pembelajarannya melalui daring maka guru harus menggunakan berbagai media dalam pembelajaran yang dimungkinkan menarik dan tidak membuat anak bosan. Pembelajaran yang berbasis teknologi yang saat ini sedang berkembang pun perlu dibuat berdasarkan karakteristik dan kompetensi pemahaman Bahasa anak. Tabel 1 menunjukkan peta kompetensi pemahaman bahasa anak usia 5-6 tahun dalam pengembagan media ARCHELI.

Tabel 1. Peta Kompetensi Pemahaman Bahasa Anak Usia 5-6 Tahun

\begin{tabular}{ll}
\hline \multicolumn{1}{c}{ Kompetensi Dasar } & \multicolumn{1}{c}{ Indikator } \\
\cline { 2 - 4 } $\begin{array}{l}\text { Memahami Bahasa reseptif } \\
\text { (menyimak dan membaca) }\end{array}$ & $\begin{array}{l}\text { Menceritakan kembali apa yang di dengar dengan } \\
\text { kosakata yang lebih }\end{array}$ \\
\hline $\begin{array}{l}\text { Menunjukkan kemampuan berbahasa reseptif } \\
\text { (menyimak dan membaca) }\end{array}$ & $\begin{array}{l}\text { Melaksanakan perintah yang lebih kompelks } \\
\text { sesuai dengan aturan yang disampaikan } \\
\text { (misalnya, aturan untuk mencuci buah sebelum } \\
\text { dimakan) }\end{array}$ \\
\hline $\begin{array}{l}\text { Memahami Bahasa ekspresif } \\
\text { (mengungkapkan bahasa verbal dan non } \\
\text { verbal) }\end{array}$ & $\begin{array}{l}\text { Pendapat dengan kalimat sederhana dalam } \\
\text { berkomunikasi dengan anak satu atau orang } \\
\text { dewasa. }\end{array}$ \\
\hline $\begin{array}{l}\text { Menunjukkan kemampuan berbahasa ekspresif } \\
\text { (mengungkapkan bahasa verbal dan non } \\
\text { verbal) }\end{array}$ & $\begin{array}{l}\text { Menunjukkan perilaku senang membaca buku } \\
\text { terhadap buku-buku yang dijumpai. }\end{array}$ \\
\hline
\end{tabular}

Tabel 2 menunjukkan rancangan peta materi yang telah dibuat dan dikembangkan dari peta kompetensi sebagai dasar pengembangan buku ARCHELI, sedangkan Tabel 3 menunjukkan rancangan isi media secara garis besar termasuk desain buku ARCHELI sebagai media pembelajaran berbasai augmented reality untuk kosa kata Bahasa Indonesia dan Bahasa Inggris.

Media augmented reality yang dikembangkan kemudian divalidasi terlebih dahulu. Validasi media dilakukan oleh ahli media yang mempunyai latar belakang berpengalaman sesuai dengan media yang dikembangkan. Tujuannya untuk mendapatkan informasi, kritik dan juga saran agar media augmented reality yang dikembangkan menjadi produk yang berkualitas secara aspek isi dan tujuan, teknis dan instruksional.

Secara umum, augmented reality dinilai cukup menarik dan menantang bagi anak dalam memperkaya kosakata Bahasa Indonesia maupun Bahasa inggris mereka. Hal ini karena adanya kenampakan suara yang muncul dan objek yang bergerak. Media ini berupa 
buku dan juga APK yang di download lewat Handphone yang memudahkan anak dalam belajar dimana saja.

Tabel 2. Peta Materi Buku Literasi ARCHELI

\begin{tabular}{|c|c|c|}
\hline Materi Pokok & Isi Materi & Penjabaran Materi \\
\hline $\begin{array}{l}\text { Memahami Bahasa reseptif } \\
\text { (menyimak dan membaca) }\end{array}$ & $\begin{array}{ll}\text { - } & \text { Mengenal } \\
\text { - } & \text { Menirukan } \\
\text { - } & \text { Menyebutkan }\end{array}$ & $\begin{array}{l}\text { Jenis-jenis gambar dan kosa yang } \\
\text { diterapkan secara sederhana seperti } \\
\text { nama buah, nama sayur dan lain } \\
\text { sebagainya. }\end{array}$ \\
\hline $\begin{array}{l}\text { Menunjukkan kemampuan } \\
\text { berbahasa reseptif (menyimak dan } \\
\text { membaca) }\end{array}$ & $\begin{array}{ll}\text { - } & \text { Mengenal } \\
\text { - } & \text { Menirukan } \\
\text { - } & \text { Menyebutkan }\end{array}$ & $\begin{array}{l}\text { Jenis-jenis gambar dan nama-nama } \\
\text { buah juga sayuran yang dapat } \\
\text { dilakukan } \\
\text { menyebutkannya. }\end{array}$ \\
\hline $\begin{array}{l}\text { Memahami Bahasa ekspresif } \\
\text { (mengungkapkan Bahasa secara } \\
\text { verbal dan non verbal) }\end{array}$ & $\begin{array}{ll}\text { - } & \text { Mengungkapk } \\
\text { an }\end{array}$ & $\begin{array}{l}\text { Anak dapat mengungkapkan apa } \\
\text { yang disampaikan oleh guru }\end{array}$ \\
\hline $\begin{array}{lr}\text { Menunjukkan } & \text { kemmapuan } \\
\text { berbahasa } & \text { ekspresif } \\
\text { (mengungkapkan Bahasa } & \text { secara } \\
\text { verbal dan non verbal) } & \end{array}$ & $\begin{array}{l}\text { Mengungkapk } \\
\text { an }\end{array}$ & $\begin{array}{l}\text { Anak dapat menebak atau } \\
\text { menyebutkan apa yang muncul di } \\
\text { handphone }\end{array}$ \\
\hline
\end{tabular}

Tabel 3: Garis Besar Media Pembelajaran berbasis Augmented Reality

\begin{tabular}{ll}
\hline Judul & $\begin{array}{l}\text { Augmented Reality for Children's Literacy } \\
\text { (ARCHELI) } \\
\text { Meningkatkan keaksaraan (kosa kata) Bahasa } \\
\text { Indonedia dan Bahasa Inggris dasar bagi anak } \\
\text { usia dini }\end{array}$ \\
\hline Indikator turunan & 1. Mampu mengenal keaksaraan awal \\
2. Mampu mengingat keaksaraan awal & 3. Mampu menyebutkan keaksaraan \\
\hline Format media & 1. Judul media 'Augmented Reality for \\
& 2. Buildren's Literacy (ARCHELI) \\
& 3. Buah-buahan dan sayuran \\
& 4. Handphone \\
Gambar design media &
\end{tabular}


Aumented Reality (AR) merupakan teknologi yang menggabungkan benda maya dua dimensi dan tiga dimensi ke dalam sebuah lingkungan nyata tiga dimensi, lalu memproyeksikan benda-benda maya tersebut ke nyata (real time). AR bertujuan untuk mengambil dunia nyata sebagai dasar dengan menggabungkan beberapa teknologi virtual dan menambahkan data konstektual agar pemahaman manusia sebagai penggunanya menjadi semakin jelas. Data konstektual ini dapat berupa computer audio, data lokasi, konteks sejarah atau dalam bentuk lainnya.

AR dapat ditampilkan pada berbagai perangkat seperti kacamata, ponsel dan sebagainya. Agar perangkat berfungsi dengan baik, sejumlah data tertentu dalam bentuk video, gambar, animasi dan model 3D perlu digunakan. Sehingga orang bisa melihat hasilnya dalam cahaya buatan dan alami. AR menggunakan teknologi SLAM (Simultaneous Localization and Mapping), sensor dan pengukur kedalaman. Mengumpulkan data sensor untuk menghitung jarak dari lokasi sensor ke objek. Beberapa komponen AR : kamera sensor, proyeksi, refleksi. Untuk jenis teknologi Augmented Reality : Marker-Based augmented reality, markerless augmented realiy, projection based augmented reality, superimposition based augmented reality.

Prinsip kerja Augmented Reality ; a) Kamera menangkap data dari marker dalam dunia nyata dan mengirimkan informasinya ke computer. b) Software pada computer akan melacak bentuk kotak dari marker dan mendeteksi berapa video framenya. c) Bila kotak telah ditemukan, maka software menggunakan perhitungan matematis untuk menghitung posisi dari kamera relative terhadap kotak hitam pada marker. d) Setelah dikalkulasi, maka model grafis akan dimunculkan pada posisi yang sama dan berada di dalam lingkup kotak hitam, lalu ditampilkan ke layer untuk melihat grafis dalam dunia nyata.

\section{Pembahasan}

Peran teknologi di era globalisasi saat ini menjadi bagian yang terpenting dalam kehidupan manusia dan memberikan hal besar dalam hal perubahan pada bidang apapun termasuk bidang di pendidikan. Melihat dari perkembangan teknologi sekarang ini, perkembangan teknologi telah berpengaruh bagi kehidupan anak sehari-hari, peran orang tua juga sangat berpengaruh terhadap perkembangan teknologi. kecanggihan teknologi ICT ini beragam informasi dari berbagai sudut dunia mampu diakses dengan instan dan cepat oleh siapapun dan dari manapun (Husain \& Kaharu, 2020)

Mungkin tanpa kita sadari bahwa anak-anak sekarang sangat bergantung dengan teknologi seperti adanya laptop, android, tablet hamper semua anak-anak sudah bias memainkannya, bahkan anak yang dibawah umur tiga tahun mereka sudah terbiasa dan bahkan mereka cenderung permainannya adalah laptop maupun android. Namun demikian Hadirnya teknologi digital dikalangan anak usia dini tentu menjadi tantangan besar khususnya bagi anak pra sekolah agar bisa melanjutkan pendidikan ke tingkat sekolah dasar (SD) (Zaini \& Soenarto, 2019). Hal ini tidak asing lagi dengan penglihatan kita, karena sudah banyak menjumpai, anak-anak lebih suka bermain dengan laptop atau gadgetnya daripada bermain dengan teman-teman sebayanya da nada juga orang tua bahkan melarang anakanaknya untuk bermain diluar rumah dengan berbagai alas an sehingga anak-anak diberikan mainan seperti laptop atau gadget sehingga anak sibuk dan asik bermain sendiri, tanpa orangtua sadari bahwa permainan seperti ini sudah membentuk perilaku anak yang tidak bisa terpisah dengan teknologi saat ini (Sumarni, 2017).

Proses pembelajaran juga memiliki peran penting dalam meningkatkan kualitas pendidikan, sehingga sudah selayaknya pembelajaran yang diselenggarakan dapat membawa manfaat bagi peserta didik. Ayuni et al. (2021) mendapati pengunaan teknologi dalam pembelajaran daring ditemukan beberapa kendala, yaitu sulitnya sinyal internet, paket data internet yang memakan biaya cukup besar, sulitnya melakukan pembelajaran yang bisa mencakup semua aspek perkembangan anak, dan sulitnya melakukan penilaian secara langsung. Manfaat dan makna pembelajaran dapat dibangun melalui penciptaan suasana 
belajar yang menyenangkan dan mampu memberikan stimulasi pada peserta didik dari berbagai aspek sekaligus membantu menggali potensi yan dimiliki anak secara optimal (Haryanti, 2021). Salah satu cara yang dapat digunakan adalah dengan membuat desain buku yang menarik sesuai dengan karakter anak.

Pengembangan desain buku menyesuaikan dengan karakter anak usia 5-6 tahun dengan materi kosa kata didasari pada sebuah game yang menarik dan sesuai dengan apa yang disukai anak. Design program Augmented Reality yang dikembangkan diharapkan dapat menjadi alternatif dalam pembelajaran penguasaan kosa kata pada anak usia 5-6 tahun. Berbeda dengan penelitian ini Prahesti et al. (2019) menggunakan media CD interaktif berbudaya sehat untuk meningkatkan kosa kata anak usia 5-6 tahun, sedangkan Nurjannah (2014) menggunakan media bergambar.

\section{SIMPULAN}

Kesimpulan yang dapat diambil dari penelitian dan pengembangan ini yaitu di dalam design produk buku sudah selesai, terdapat berbagai pengembangan konsep buku, konten materi berupa kosa kata yang disesuaikan dengan karakteristik belajar Bahasa anak usia 5 - 6 tahun, yang didasarkan pada sebuah games. Design program Augmented Reality yang dikembangkan masih terkendala pada pemilihan versi unity yang kurang cocok dengan perangkat yakni yang digunakan untuk mengembangkan media. Kendala lain yang masih terjadi yakni pada proses rendering ke dalam bentuk APK. Oleh karena itu penelitian dan pengembangan ini masih dapat dilanjutkan untuk memperoleh hasil prototype produk final untuk dapat digunakan secara terbatas.

\section{UCAPAN TERIMA KASIH}

Peneliti mengucapkan terimakasih kepada kedua orangtua dan juga Dosen Pembimbing yang telah memberikan semangat dan dukungan kepada penulis sampai penelitian ini selesai. Ucapan terimakasih uga disampaikan kepada tim editor Jurnal Obsesi yang telah memberikan saran, kritik dan juga masukan untuk perbaikan artikel ini.

\section{DAFTAR PUSTAKA}

Arifa, F. N. (2020). Tantangan Pelaksanaan Kebijakan Belajar dari Rumah dalam Masa Darurat Covid-19. Info Singkat.

Ayuni, D., Marini, T., Fauziddin, M., \& Pahrul, Y. (2021). Kesiapan Guru TK Menghadapi Pembelajaran Daring Masa Pandemi Covid-19. Jurnal Obsesi : Jurnal Pendidikan Anak Usia Dini, 5(1), 414-421. https://doi.org/10.31004/obsesi.v5i1.579

Dhiu, K. D. (2021). Aspek Perkembangan Anak Usia Dini. Pekalongan: NEM-Anggota IKAPI.

Gall, B. a. (2020). Penelitian Pengembangan (Research and Development). 772.

Gunarti, W. (2018). Penerapan Motode Bermain Peran untuk Meningkatkan Bahasa pada Anak. Raden Intan, 41.

Haryanti, S. D. (2021). Pemanfaatan Teknologi dalam Pendidikan Anak Usia Dini. Kompasiana.

Husain, R., \& Kaharu, A. (2020). Menghadapi Era Abad 21: Tantangan Guru Pendidikan Anak Usia Dini di Kabupaten Bone Bolango. Jurnal Obsesi : Jurnal Pendidikan Anak Usia Dini, 5(1), 85. https:// doi.org/10.31004/obsesi.v5i1.527

Indrawati. (2017). Pendidikan Anak Usia Dini pada Masa Golden Age. Journal of Islamic Studies.

Kemendikbud. (2014). Permendikbud 146 Tahun 2014 Tentang Kurikulum. Permendikbud.

Kurniawan, M. (2017). Mobile Learning in TESOL: A Golden Bridge for Enhancement of Grammar Awareness and Vocabulary Mastery. Asian EFL Journal.

Mulyana, A. (2020). Penelitian Pengembangkan Research and Development. Latest. 
Musabikhah \& Usman. (2021). Meningkatkan Kemampuan Keaksaraan pada Masa Pandemi Covid19 Melalui Program Pembelajaran Virtual. Seminar Nasional Hasil Riset dan Pengabdian.

Novita, C. C. (2020). Penggunaan Mainan Kartu Kata Membaca Berputar Berbasis Teknologi Untuk Anak Usia Dini. Journal on Early Childhood. https:// doi.org/10.31004/aulad.v3i3.82

Nurjannah. (2014). Peningkatan Kemampuan Penguasaan Kosakata melalui Kartu Huruf Bergambar Siswa Kelas II SDN 5 Soni. Jurnal Kreatif Tadulako, 4(8), 290-313.

Nurlaeni. (2020). Analisis Perkembangan Bahasa Anak. PAUDIA.

Ozarslan, K. (2012). Studi Literatur Pemanfaatan Media Augmented Reality. Unesa.

Permendikbud. (2014). Permendikbud 137 Tentang Kurikulum 2014. Permendikbud.

Prahesti, S. I., Taulany, H., \& Fauziah, S. (2019). Media Compact Disk Interaktif Berbudaya Sehat untuk Meningkatkan Kosa Kata Anak Usia Dini. Jurnal Obsesi : Jurnal Pendidikan Anak Usia Dini, 3(2), 377. https:// doi.org/10.31004/obsesi.v3i2.149

Rosaliana. (2011). Pembelajaran Bahasa Indonesia. Jurnal Nasional UMP, 19.

Sugiono. (2012). Metode Penelitian. Alfabeta.

Sumarni, T. (2017). Peran Teknologi Terhadap Anak Usia Dini. Kompasiana.

Syaodih, E. (2019). Perkembangan Anak Usia Dini. Golden Age.

Usman, N. (2021). Meningkatkan Kemampuan Keaksaraan Pada Masa Pandemi Covid-19 Melalui Program Pembelajaran Virtual. Seminar Nasional Hasil Riset dan Pengabdian.

Vijayani, E. R. (2013). Media Pembelajaran Pengenalan Buah. Semarang.

Yaoyuneyong, G. (2011). Penerapan Augmented Reality sebagai Media Bantu Pembelajaran. Pendidikan Teknologi dan Kejuruan.

Yemima, M. (2019). Enhancing English Vocabulary Through The Use of Snacke and Ladder Media for 4 to 6 Years Old Children. Satya Widya. https://doi.org/10.24246/j.sw.2019.v35.i1.p1-15

Yemima, Wijayaningsih, Kurniawan. (2019). Enhancing English Vocabulary Through The Use Of Snake And Ladder Media For 4 To 6-Year-Old Children. Satya Widya, 1-15. https:// doi.org/10.24246/j.sw.2019.v35.i1.p1-15

Yulaelawati, E. (2016). Keaksaraan Awal.

Zaini, M., \& Soenarto, S. (2019). Persepsi Orangtua Terhadap Hadirnya Era Teknologi Digital di Kalangan Anak Usia Dini. Jurnal Obsesi : Jurnal Pendidikan Anak Usia Dini, 3(1), 254. https:// doi.org/10.31004/obsesi.v3i1.127 